\title{
Economic Assessment of European Beech and Turkey Oak Stands with Close-to-Nature Forest Management
}

\author{
Péter CSÉPÁNYI ${ }^{\mathrm{a}^{*}}-$ Attila CSÓR $^{\mathrm{b}}$ \\ ${ }^{\text {a }}$ Pilis Park Forestry Company, Visegrád, Hungary \\ ${ }^{\mathrm{b}}$ Budapest Forestry Company, Buják, Hungary
}

\begin{abstract}
The paper analyses the complex economic models of continuous cover forestry based on the 'Dauerwald' principles in the early transformation period and in the traditional rotation system both in European beech (Fagus sylvatica L.) and Turkey oak (Quercus cerris L.) stands in central Hungarian study sites. The analysis was carried out on both the stand and estate-levels, and the performances were compared as well. We found that continuous cover forest management (CCF) can achieve at least the same economic efficiency as traditional rotation forest management (RF) in both beech and in Turkey oak stands. The regeneration problems occurring in poor quality sites in Turkey oak stands made visible the economic differences between the two management systems investigated.
\end{abstract}

European beech / Turkey oak / continuous cover forest management / rotation forest management / annuity

Kivonat - Természetközeli erdőgazdálkodás ökonómiai értékelése bükk és cser állományokban. A tanulmány bemutatja az örökerdő elvek szerint folyamatos borítást biztosító erdőgazdálkodással kezelt bükkösök (Fagus sylvatica L.) és cseresek (Quercus cerris L.) kezdeti átvezetési időszakának adataiból, és a hagyományos vágásos erdőgazdálkodás adataiból felállított komplex ökonómiai modellek elemzését a Közép-Magyarországon található vizsgálati területeken. Az elemzés erdőrészlet és erdőtömb (üzemi) szinten hasonlítja össze a gazdasági teljesítményeket. Megállapítható, hogy a bükkösökben és a cseresekben örökerdö-gazdálkodás mindkét szinten legalább olyan ökonómiai teljesítményre képes, mint a hagyományos vágásos üzemmód. A gyenge termőhelyü cseresekben jelentkező felújítási problémák rövid idő alatt láthatóvá tették a két gazdálkodási rendszer közötti ökonómiai különbségeket.

bükk / cser / örökerdő-gazdálkodás / vágásos erdőgazdálkodás / annuitás

\section{INTRODUCTION}

A topical question in contemporary forestry is the comparison of the continuous cover forest management system (CCF) (Pommerening - Murphy 2004, Knoke 2012) and traditional rotation forest management (RF) methods. From an economic point of view, the most important advantages of CCF (the English translation of 'Dauerwaldwirtschaft') are the stability of uneven-aged forests and evenly distributed logging, which has a positive effect on

\footnotetext{
* Corresponding author: csepanyi.peter@pprt.hu; H-2025 VISEGRÁD, Mátyás k. u. 4, Hungary
} 
profitability and is also able to mitigate the fluctuation of wood prices (Knoke 2010, 2012). Based on the research of Knoke (2010) carried out in twelve European (German-speaking) regions as a comparative analysis, 'Dauerwald' forest management methods never showed a disadvantage; when comparing 'Dauerwald' forest management in English-speaking areas, a disadvantage was found only three times out of twelve sites.

As was the case in the rest of Europe, many professionals in Hungary turned their attention to this topic at the end of the nineteenth century and in the twentieth century; however, Hungarian professionals did so in theory rather than in practice. Objections and resistance to $\mathrm{CCF}$, which has been considered inferior to RF mainly for economic reasons, have lingered until now (Knoke 2012).

Hungarian silviculturists (Jablánczy 1953, Roth 1958, Majer 1986) showed great concern about the 'Dauerwald' idea in the 1950s and early 1960s. Therefore, a selective cutting experiment was initiated in 1954 on 22.98 ha of the Visegrád 77A subcompartment (Madas 1956). Today, Pilis Park Forestry Company (PPF) manages this site. It is one of the few forerunners of CCF in Hungary mentioned by Roth (1958) and Majer (1986), in addition to the selection forest managed by Roth in Sopron (Koloszár 2013). However, the development wound down by the late 1960s, and there was no further progress until the 1990s.

Criticism over the use of traditional RF methods increased in the 1990s among nature conservationists and the Hungarian public alike. To address this criticism, some private forest owners, state forestry companies, and the PPF especially, began to revive CCF approaches.

According to official statistics (NÉBIH 2016), the total forested area in Hungary is $1,940,700$ hectares, of which $55 \%$ belongs to the state, $1 \%$ to local communities, and $44 \%$ to private owners. The PPF is one of the twenty-two state-owned companies that manage state forests. The PPF manages 58,051 hectares of state forests in the Pilis, Visegrád, Gerecse, and Buda Mountains, Gödöllö Hills, on the Danube islands of Szentendre and Csepel, and on the Csepel Plain. These forests represent an invaluable resource for Hungary's capital city Budapest as well as the surrounding urban areas as they provide recreational possibilities and facilities to millions of visitors. The proportion of protected areas (including Natura 2000) is $74 \%$, which is among the highest in Hungary.

The first step of resuming CCF was the establishment of an exemplary area based on Pro Silva principles. This came to be in 1999 in the subcompartment of Pilisszentlélek 25A, a 9.74 ha mixed beech stand. The company level introduction of CCF began in 2002 when the most suitable areas - mainly beech forests - were gradually marked out (Csépányi 2012, Csépányi 2016). PPF's vision regarding the introduction of CCF is to make it large scale enough to help integrate higher-level nature conservation (Boncica 2011) and public welfare aspects into forestry practices as these are important to the community.

This paper deals with the economic valuation derived from the already gathered practical experience of CCF introduced on a company level in European beech (Fagus silvatica L.) and Turkey oak (Quercus cerris L.) stands managed by PPF. The CCF management at PPF is based on the so-called 'Dauerwald' concept defined by Möller (1922) (Troup 1927, Thomasius 1996, Helliwell 1997) and on the principles of Pro Silva (1996, 2012).

The most important criteria of CCF are:

- Avoidance of clear cuts or final cuts and a rotation age. Felling of single trees, tree groups, or trees standing in gaps is done due to their individual maturity. There is no regular, traditional felling area. However, groups or gaps can be made according to the light demand of given species. Uneven-aged mixed forests provide protection for the soil and sustain maximal productiveness with continuous forest cover.

- The basis of regulation in a given subcompartment is the actual increment determined periodically as well as the relation between the optimal and actual living stock (control method). 
- Single trees or groups have to be harvested at the peak of their value; well performing ones have to be kept and poorly performing ones can be felled.

- Regeneration is a secondary aspect; it appears spontaneously. However, it has to have high density and good quality to complement the trees and tree groups harvested from the area.

- The consideration of biological aspects, dead wood, and biodiversity during forest management practices.

The subject of our research was a model-based economic analysis and comparison of forests managed with the RF and CCF systems. Beech forests cover the company's good sites where the CCF system has been easier to implement after it was successfully introduced in 2002. In the poor sites where Turkey oak stands dominate, mainly on the sandy soils of the Gödöllö Hills, the common cockchafer (Melolontha melolontha L.), the forest cockchafer (Melolontha hippocastani F.), and periodic drought inflicted severe damage on the regeneration. This damage made RF methods very expensive. The possibility of introducing $\mathrm{CCF}$ in these sites, considering that light-demanding tree species are dominant, has not been generally admitted among professionals. Therefore, it was particularly interesting to compare the CCF and RF systems to investigate what kind of effects can be observed both at better and at poorer sites. At the international level, studies comparing CFF and RF systems in beech or in silver fir-Norway spruce-European beech mixed stands exist; however, assessments of this kind in Turkey oak stands are rare.

\section{MATERIALS AND METHODS}

\subsection{Study sites}

The 58,051 hectares state forest managed by PPF (Figure 1) includes $32 \%$ oak (Quercus petraea Liebl., Quercus robur L., Quercus pubescens Willd.), 25\% Turkey oak, 6\% beech, 7\% hornbeam (Carpinus betulus L.), 10\% black locust (Robinia pseudoacacia L.), 3\% ash (Fraxinus excelsior L., Fraxinus ornus L., Fraxinus angustifolia Vahl. subsp. pannonica Soó et Simon), 9\% other hardwoods, poplar 2\%, conifers 6\%). Due to the consequent process of introducing CCF in 2002, the forest areas managed with different systems at the end of 2016 were as follows: 7,157 ha were CCF system, 7,175 ha were transitional management system (transition from RF to $\mathrm{CCF}$ ), 36,149 ha were RF, and 7,570 ha were non-timber production forests.

The assessment area in $2^{\text {nd }}$ yield class beech stands between CCF and RF systems was at the Pilisszentkereszt Forestry Unit and the Pilismarót Forestry Unit of PPF in the Pilis and Visegrád Mountains, 300-700 m above sea level. Its climate is moderate with a mean annual temperature between 9.3-9.7 $\mathrm{C}^{\circ}$, and an annual precipitation of $600 \mathrm{~mm}$. The 44 subcompartments were situated in the administrative area of settlements Pilisszentkereszt, Pilisszentlélek, Pilismarót, and Dömös; the total area was 359.8 ha. The RF system was investigated in a total area of 183.5 ha according to the management plans of Pilismarót Forestry Unit 1981-2011 (in subcompartments: Dömös 5B, 6A, 26E, 29A, 30C, 39C; Pilismarót 54 B, 55C, 57A, 61B, 63D,F, 124A, 125B, 126A,B,C,D, 128A, 129B, 134A, 136A, 139A, 140A). The CCF system was assessed in a total area of 176.3 ha according to the management plan of Pilisszentkereszt Forestry Unit 2002-2011 (in subcompartments: Pilisszentkereszt 3A, 4B, 6C, 8B, 9A, 11A, 14A,C, 15A, 16A, 29B, 30C; Pilisszentlélek 16B, 23A, 24A,B, 26A, 27A, 28A,B). 


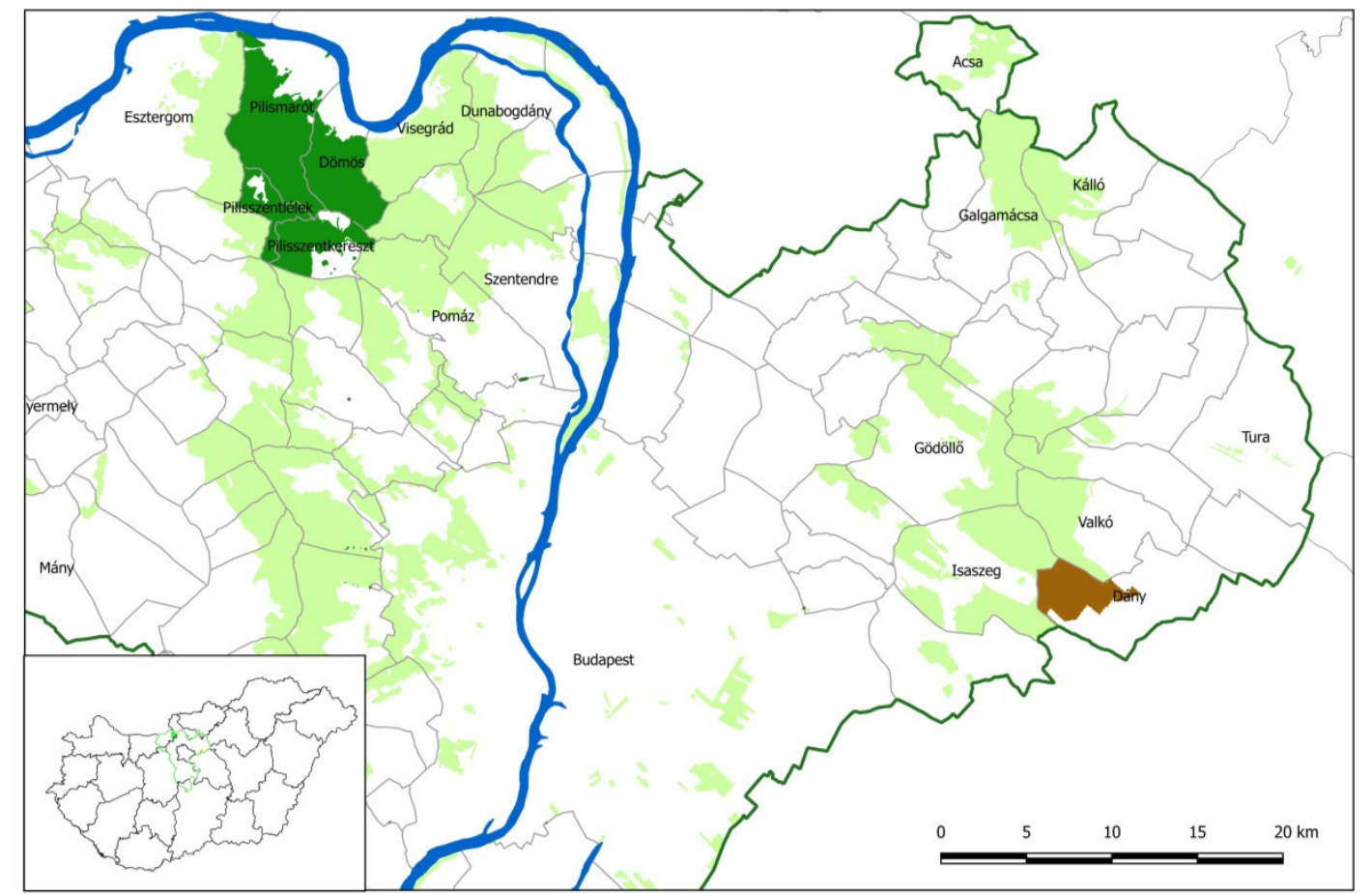

Figure 1. Location of assessment area by Pilis Park Forestry Company in Hungary. (The green line is the border of the company; the pale green areas: state forest managed by PPF; the dark green area is the administrative area of the Pilismarót, Dömös, Pilisszentlélek, Pilisszentkereszt settlements: beech assessment, the brown area marks the administrative area of Dány settlement: Turkey oak assessment)

The assessment area in $4^{\text {th }}$ yield class Turkey oak stands between CCF and RF systems was situated at the Valkó Forestry Unit in the Gödöllö Hills, 150-250 m above sea level. The annual mean temperature here is $10.2{ }^{\circ} \mathrm{C}$ and the annual precipitation is $540 \mathrm{~mm}$. Severe heat and drought occur here annually in July and August; artificially planted seedlings are often scorched at this time. The six subcompartments were in the administrative area of the Dány settlement and the total area was 43.4 ha. The RF system in the clearcutting with artificial regeneration in the Dány 25B, 40A, 40C subcompartments has an assessment area of 15.1 ha. The RF system in regeneration cutting with natural regeneration has an assessment area of 16.3 ha in the Dány $11 \mathrm{C}$, 44E subcompartments, and the CCF system has a 12.0 ha area in the Dány 28A subcompartment. The subcompartment data originate from the management plan of Valkó Forestry Unit 1990-2011.

\subsection{Methods of economic analysis}

To carry out the economic analysis, the method of complex economic models (Márkus and Mészáros 2000, Marosi 2005, Marosi and Juhász 2011) was applied using the management data of PPF. The data of exploited gross volume by the different cutting methods and by subcompartments were collected from the registering part of management plans.

During the establishment of the RF model in the case of beech stands, $2^{\text {nd }}$ yield class beech forests at the Pilismarót Forestry Unit between the ages of 24 and 123 years (183.5ha) that have an approximately similar mixture were used.

The empirical model of CCF was created from the data collected in the management plan period of 2002-2011 at the Pilisszentkereszt Forestry Unit. In this system, the last ten years of interventions were examined in beech stands in the $2^{\text {nd }}$ yield class in a similar area (176.3 ha); 
their ages were between 49 and 109 years. The cutting method was a combination of single tree and group selection.

Contrary to the calculation made in beech forests (Schiberna et al. 2012, Csépányi 2013), in the case of Turkey oak stands (Csépányi - Csór 2014) the comparison was simplified and only deals with the examination of the different methods of RF and CCF beyond middle age and regenerations including the first cleaning. This way the data of the further cleanings and thinnings in young and middle-aged stands are lacking and can be viewed as the same respectively. Subcompartments (43.4 ha) that were situated close to each other where the process of regeneration had already begun were examined. Due to the negligible distance, the site conditions and yield classes were equal ( $4^{\text {th }}$ yield class). The development phase of regenerations was not the same; thus, the cost analysis is based on the data originating from the six subcompartments with different development levels. In this way, practical models were assembled from the given subcompartments. The area within the Valkó Forestry Unit (Dány settlement) suffers especially from regeneration problems because of the damage to seedling roots caused by the grubs of the cockchafer species or the climatic and soil condition issues mentioned above. The stands mostly contain Turkey oak, but they also have a few per cent of other oak species.

Basic data gathered for the analysis are as follows: exploited volumes are taken from the registering part of the management plan, while net prices and costs are taken from the financial accounts of the PPF. The data collected from the management plans and the accounting system were uploaded on Microsoft Excel worksheets and the calculations were carried out by means of the software.

The economic evaluation is done on two levels: firstly on the stand-level, which can be important for smallholding forest owners, and secondly on the estate or enterprise-level (Schiberna et al. 2012) in order to have sufficient areas to represent the conclusions derived from the calculations.

\subsubsection{Stand-level analysis}

To be able to process the data at the stand-level, the method of determining equal annual cash flows is used for analysis; based on earlier professional literature, this is known more commonly as annuity (Schiberna et al. 2012, Márkus and Mészáros 2000), which is a series of equal cash flows over a fixed period time (rotation period, return cycle of single tree or group selection). If this time limit is infinite, we get to the definition of perpetuity. By comparing the annuity of different management systems the economic performance of the two management types can be compared on a stand-level. 
Periodic annuity of RF system:

where:

$$
P A_{R F}=\sum_{t=1}^{f} C F_{t}(1+r)^{f-t}
$$

$P A_{R F}$ : Periodic annuity of the RF system at the end of the rotation

$C F_{t}$ : net cash flow of the $\mathrm{t}^{\text {th }}$ year, balance of the incomes and expenses during management processes (logging, regeneration, silviculture)

$f: \quad$ harvesting age

$t$ : $\quad$ year of forest management interventions

$r$ : interest rate

Annuity of forests managed with the RF system:

where:

$$
A_{R F}=P A_{R F} \frac{r}{(1+r)^{f}-1}
$$

$A_{R F}: \quad$ annuity with the RF system

$P A_{R F}$ : Periodic annuity of the RF system at the end of the rotation

$f: \quad$ harvesting age

$r: \quad$ interest rate

Annuity of forests managed with the CCF

where:

$$
A_{C C F}=C F_{C} \frac{r}{(1+r)^{c}-1}
$$

$A_{C C F}$ : annuity in the given cycle of $\mathrm{CCF}$

$C F_{c}$ : net cash flow of the $c^{\text {th }}$ year, balance of the incomes and expenses during management processes (logging, regeneration, silviculture)

$c: \quad$ cycle, return period of CCF felling interventions

$r$ : interest rate

\subsubsection{Estate-level analysis}

The comparison of forest estates on a large-scale is also done by defining annuity. In this case - assuming regular conditions - the annual revenues equalize, and interest plays no role in the calculations. The forest estates in the RF system are considered as a fully regulated 'normal forest'.

Annuity of the management system in the case of a regular forest estate

where:

$$
A_{E}=\sum_{i=1}^{m} C F_{i}
$$

$A_{E}: \quad$ annuity of the forest estate

$C F_{i}$ : net cash flow of the $i^{\text {th }}$ age class, balance of the incomes and expenses during management processes (logging, regeneration, silviculture)

$i$ : number of the given age-class

$m: \quad$ number of all age-classes

\section{RESULTS AND DISCUSSION}

Basic data in the tables were gathered for complex economic models, and results were provided by the processing methods mentioned above. 


\subsection{Beech stands RF system - regeneration cutting with natural regeneration}

For a beech stand in the RF system (Table 1, Table 2), the average gross yield per hectare can be calculated on $786 \mathrm{~m}^{3}$ and the average net yield can be calculated on $698 \mathrm{~m}^{3}$ with a 120 year old harvesting age. Each ten-year age class had enough area. Depending on the age, subcompartments from 2011 dating back thirty years were examined (1981-2011).

Data about the date of interventions were sorted as follows: the age of the stand at the intervention, cutting methods, and logged gross timber volumes. With the help of these data, an empirical model could be set up. The cutting method in these beech stands is gradual regeneration cutting with a rotation of 120 years where the initial intervention is mostly done by a uniform shelterwood cutting and later interventions are mainly done in a group pattern or combined. The data about timber assortment structure were taken from the period between 2005 and 2011 net selling prices, and net costs were taken from the last two years (2010, 2011). Sales data are collected only from the prices of beech products; therefore, the incidentally present differences in species composition do not disturb evaluation. Forest regeneration expenses were calculated using the 2011 costs based on the regeneration practices used in the Pilismarót Forestry Unit.

Table 1. The empirical natural model of the RF system in beech stands without regeneration (1ha)

\begin{tabular}{|c|c|c|c|c|c|c|c|c|c|c|c|c|}
\hline Age classes & $\mathrm{yr}$ & $11-20$ & $21-30$ & $31-40$ & $41-50$ & $51-60$ & $61-70$ & $71-80$ & $81-90$ & $91-100$ & $101-110$ & $111-120$ \\
\hline \multirow[t]{4}{*}{$\begin{array}{l}\text { Management } \\
\text { methods }\end{array}$} & - & 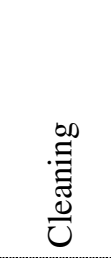 & 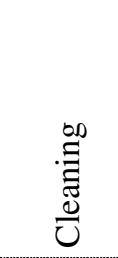 & 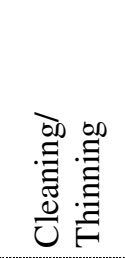 & 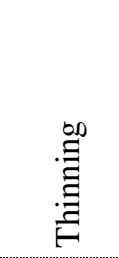 & 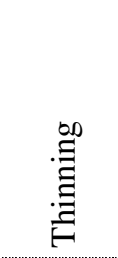 & 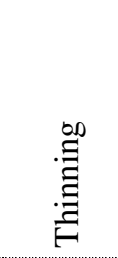 & 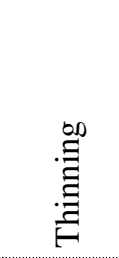 & 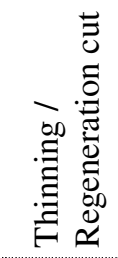 & 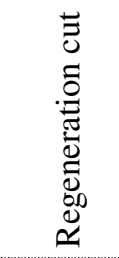 & 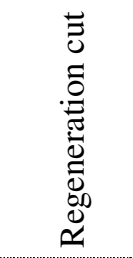 & 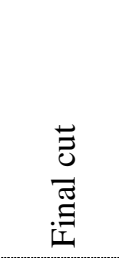 \\
\hline & $\begin{array}{l}\text { (Gross } \\
\left.\mathrm{m}^{3} / \mathrm{ha}\right)\end{array}$ & 2.1 & 6.1 & 31.3 & 40.8 & 29.4 & 36.7 & 104.7 & 37.9 & 72.7 & 73.5 & 351.1 \\
\hline & $($ Net $\%)$ & $69 \%$ & $69 \%$ & $69 \%$ & $69 \%$ & $83 \%$ & $83 \%$ & $88 \%$ & $93 \%$ & $93 \%$ & $93 \%$ & $93 \%$ \\
\hline & $\begin{array}{l}\text { (Net } \\
\left.\mathrm{m}^{3} / \mathrm{ha}\right)\end{array}$ & 1.5 & 4.2 & 21.6 & 28.2 & 24.3 & 30.4 & 91.8 & 35.1 & 67.3 & 68.1 & 325.1 \\
\hline $\begin{array}{l}\text { Specific } \\
\text { revenues }\end{array}$ & $\begin{array}{l}\text { (HUF / } \\
\left.\text { net } m^{3}\right)\end{array}$ & 10,400 & 10,400 & 12,400 & 12,400 & 13,360 & 13,360 & 13,360 & 15,070 & 15,070 & 15,070 & 15,070 \\
\hline
\end{tabular}

The following complex model (Table 2) could be set up for the thirty years preceding 2011 in the beech stands of the RF system.

A benefit of the RF system is that later harvesting damage to regeneration does not need to be dealt with. Nonetheless, the lack of shade from older generations creates a constant need for nursing and other interventions to control mixture rates and stem number. 
Table 2. The empirical economic model in beech stands (2 $2^{\text {nd }}$ yield class) managed by the $R F$ system, cash flow and annuity $(r=0.02)$

\begin{tabular}{|c|c|c|c|c|c|c|c|c|c|}
\hline \multirow{3}{*}{ Intervention } & \multirow[b]{2}{*}{ Age } & \multirow[b]{2}{*}{ Yield } & \multicolumn{2}{|c|}{ Unit prices, fees } & \multicolumn{4}{|c|}{ Cash flows } & \multirow[b]{2}{*}{ Annuity } \\
\hline & & & Price & $\begin{array}{l}\text { Logging } \\
\text { fee }\end{array}$ & Income & $\begin{array}{c}\text { Logging } \\
\text { cost }\end{array}$ & $\begin{array}{r}\text { Regenera- } \\
\text { tion cost }\end{array}$ & Balance & \\
\hline & (yr) & $\left(\mathrm{m}^{3} / \mathrm{ha}\right)$ & \multicolumn{2}{|c|}{$\left(\mathrm{HUF} / \mathrm{m}^{3}\right)$} & \multicolumn{4}{|c|}{ (HUF/ha) } & $\begin{array}{l}\text { (HUF } \\
\text { /ha/yr) }\end{array}$ \\
\hline Cleaning & 20 & 2 & 10,400 & 0 & 20,800 & 0 & 26000 & $-5,200$ & -77 \\
\hline Cleaning & 30 & 4 & 10,400 & 0 & 41,600 & 0 & 24000 & 17,600 & 214 \\
\hline Thinning & 40 & 22 & 12,400 & 3,600 & 272,800 & 79,200 & 0 & 193,600 & 1,933 \\
\hline Thinning & 50 & 28 & 12,400 & 3,600 & 347,200 & 100,800 & 0 & 246,400 & 2,018 \\
\hline Thinning & 60 & 25 & 13,360 & 3,500 & 334,000 & 87,500 & 0 & 246,500 & 1,656 \\
\hline Thinning & 70 & 30 & 13,360 & 3,500 & 400,800 & 105,000 & 0 & 295,800 & 1,631 \\
\hline Thinning & 80 & 92 & 13,360 & 3,500 & $1,229,120$ & 322,000 & 0 & 907,120 & 4,102 \\
\hline $\begin{array}{l}\text { Thinning/ } \\
\text { Regeneration cut }\end{array}$ & 90 & 35 & 15,070 & 3,400 & 450 & 119,000 & 0 & 408,450 & 1,515 \\
\hline Regeneration cut & 100 & 67 & 15,070 & 3,400 & $1,009,690$ & 227,800 & 0 & 781,890 & 2,380 \\
\hline Regeneration cut & 110 & 68 & 15,070 & 3,400 & $1,024,760$ & 231200 & 0 & 793,560 & 1,981 \\
\hline Final cut & 120 & 325 & 15,070 & 3,400 & $4,897,750$ & $1,105,000$ & 270,000 & $3,522,750$ & 7,215 \\
\hline Total 120 years & - & 698 & 14,478 & 3,406 & $10,105,970$ & $2,377,500$ & 320,000 & $7,408,470$ & 24,569 \\
\hline
\end{tabular}

\subsection{Beech stands the CCF system}

In the CCF system (Table 3), based on the facts of the ten-year period, a 744 net $\mathrm{m}^{3}$ volume was calculated for a 120 -year period. The data of gross timber volume harvested in the tenyear period were collected. In this period, the total yield in the assessment area was 13,435 gross $\mathrm{m}^{3}, 76$ gross $\mathrm{m}^{3}, 62$ net $\mathrm{m}^{3}$ per hectare. The return cycle of logging interventions was five years with 31 net $\mathrm{m}^{3}$ per hectare. The method of determining assortment structure, prices, and costs was the same as for the traditional RF system.

Table 3. The empirical economic model in beech stands ( $2^{\text {nd }} 5$ yield class) managed by the CCF system, cash flow and annuity $(r=0.02)$

\begin{tabular}{|c|c|c|c|c|c|c|c|c|}
\hline \multirow{3}{*}{ Intervention } & \multirow[b]{2}{*}{ Cycle } & \multirow[b]{2}{*}{ Yield } & \multicolumn{2}{|c|}{ Unit prices, fees } & \multicolumn{3}{|c|}{ Cash flows } & \multirow[b]{2}{*}{ Annuity } \\
\hline & & & Price & $\begin{array}{l}\text { Logging } \\
\text { fee }\end{array}$ & Income & $\begin{array}{c}\text { Logging Regeneratio } \\
\text { cost cost }\end{array}$ & $\overline{\mathrm{n}}$ Balance & \\
\hline & (yr) & $\left(\mathrm{m}^{3} / \mathrm{ha}\right)$ & \multicolumn{2}{|c|}{$\left(\mathrm{HUF} / \mathrm{m}^{3}\right)$} & \multicolumn{3}{|c|}{ (HUF/ha) } & (HUF/ha/yr) \\
\hline Selection cut & 5 & 31 & 14,350 & 3,400 & 444,850 & $105,400 \quad 2,500$ & 336,950 & \\
\hline Total 120 years & - & 744 & - & - & $10,676,400$ & $2,529,600 \quad 60,000$ & $8,086,800$ & 64,748 \\
\hline
\end{tabular}

According to the results, the income in beech CCF forests kept up with the forests managed in the RF system. In the long term, the expected income can increase for CCF because single-tree or group selection concentrates on obtaining the highest value of each stem (Knoke 2010, 2012). The income counts as a good performance since in the early stage of CCF the removal of stems with lower performance dominated. In the next 20-40 years, quality loss in the mother stand will not be a consideration (Tarp et al. 2000). This is confirmed by the fact that the specific income of the subcompartment Visegrád 77A, consisting of an uneven-aged stand (24-159 year old trees mainly in the 3rd yield class), was 
$14,285 \mathrm{HUF} / \mathrm{m}^{3}$ in 2012 . It is worth starting the establishment of CCF prudently in time. When CCF starts in 50-70 year old forests, the quality loss of the mother stand will not have a significant impact on the average income for the next 70 years (Tarp et al. 2000). Thinner stems of good quality are usually present on a greater scale in the main and lower layers at $\mathrm{CCF}$, which grow valuable yield faster after removing thicker trees that have already reached their highest value. A possible explanation for this is that leaving thicker stems in the RF system is more observable due to bigger seed producing crowns and the prevention of felling damage (Froehlich 2011), which makes the exploitation of maximal value of individual stems more difficult. Another consideration in the RF system is the lack of thicker timber in young and medium age classes, which has a negative impact on income. However, based on practical experience, it is notable that the timber volume of felled trees bigger than $50 \mathrm{~cm}$ $\mathrm{DBH}$ in beech stands managed by $\mathrm{CCF}$ exceeds $50 \%$ of the total timber volume logged (Wobst 2006).

The logging costs for CCF did not exceed the usual costs for traditional RF (Table 2). The logged timber volume per hectare during the interventions is similar to a thinning volume; but the average thickness of the timber is significant. Evaluation of harvesting cost by RF systems is deceptive as the specific costs of final or clearcutting were commonly taken into consideration without considering the higher logging costs of cleanings and thinnings (Price - Price 2008). At the establishment of uneven-aged forests, logging requires greater preparation; this incurs a cost increasing effect. However, the question is how the positive effect of thick average stems can balance this out. Forest accessibility was good in the examined areas; during logging works we supplemented the already established forest roads with permanent extraction lines every 40-50 meters. During logging, the trees are felled onto or towards the lines. After debranching and chopping, the winching of further stems is done first. This makes the work of forwarders easier and more effective as they do not have to search for the timber and just work on the previously marked extraction lines.

There were no regeneration or cleaning costs in beech CCF forests during the examined period; nevertheless, a high abundance of good quality beech regeneration became established, so a significant part of the area is covered with regrowth of various density of 30-50 thousand pcs/ha and often 5-6 meter high mixed young beech groups of good quality. The explanation for this is the natural regeneration occurring during biological rationalization (Turckheim 2006, Schütz 2011, Froehlich 2011) and later the natural selection and decrease in stem numbers due to the shading of higher layers. However, the regeneration cost shown in Table 3 serves as a financial security for unforeseen cases such as securing the quality of regrowth, for example.

\subsection{Turkey oak stands in RF system - clearcutting with artificial regeneration}

In the case of Turkey oak clearcutting (Table 4 and Table 5), the regeneration was intended to start naturally, but the seedlings completely perished because of cockchafer grub damage. Therefore, a total soil preparation was done and artificial regeneration was initiated. The soil was sterilized with pesticide concurrently with a deep ploughing. A further goal of the total soil preparation was to improve the hydrology of the dry sand. Primary planting was done with one-year-old Turkey oak seedlings mixed with sessile oak and small-leaved linden. On top of this, grey poplar (Populus $x$ canescens Sm.) was planted as a shading layer because practice showed that grub damage ends after the closure of the regeneration. Due to the faster growth rate of grey poplar and interrow discing, the shading layer became established in the second year, which prevents the sand from heating up lessening the damage of heat demanding grubs. Soil sterilization was done in a part of the area in the fourth year; during the replacement of grub damaged seedlings, pesticide was applied to the root zone. Root 
development of the rapid growing poplars is more intensive as well, so they can provide an alternative food source under the ground, thereby protecting the target species of the stand from total destruction. The shading layer of grey poplar is gradually cleaned out during the development of the reforestation; the grey poplar can also disappear completely by the age of 15-20 years. Continuous soil cultivation between the rows of the reforestation is important as it aids the growth of trees by supressing weeds. Establishment regeneration cost values in the case of RF systems exceed the national average on a bigger scale in the case of artificial regeneration because of the site conditions and different damage types (Nagy 2013). Based on the references, the establishment cost value of reforestations on terrain accessible with machines was $522,000 \mathrm{HUF} / \mathrm{ha}$ in case of acorn planting ( $7^{\text {th }}$ year). In our examination the cost of artificial regeneration with seedlings was $1,680,000 \mathrm{HUF} /$ ha (in $7^{\text {th }}$ year). These values can be found elsewhere as well, mainly in cockchafer grub damaged areas (Babics 2014).

Table 4. The model of artificial reforestation (after clearcutting) in Turkey oak stands ( $4^{\text {th }}$ yield class) in the $R F$ system

\begin{tabular}{|c|c|c|c|c|c|c|}
\hline \multirow{4}{*}{ Year } & \multirow{4}{*}{ Intervention } & \multicolumn{5}{|c|}{ Expenditures for 1 ha } \\
\hline & & \multicolumn{3}{|c|}{ Material/Energy } & \multirow[b]{3}{*}{$\begin{array}{l}\text { Thousand } \\
\text { HUF }\end{array}$} & \multirow[b]{3}{*}{$\begin{array}{l}\text { Thousand } \\
\text { HUF }\end{array}$} \\
\hline & & & Quantity & Cost & & \\
\hline & & & $\begin{array}{c}\mathrm{pcs} / \mathrm{kg} / \\
\text { work hours }\end{array}$ & $\begin{array}{l}\text { Thousand } \\
\text { HUF }\end{array}$ & & \\
\hline & Total soil preparation & & & & 330.0 & 330.0 \\
\hline & Soil sterilization & Force $1.5 \mathrm{G}$ & $25 \mathrm{~kg}$ & 45.0 & & 45.0 \\
\hline & Primary planting with seedlings & $\begin{array}{l}\text { Turkey oak, sessile } \\
\text { oak, small-leaved } \\
\text { linden, grey poplar }\end{array}$ & $10,000 \mathrm{pcs}$ & 150.0 & 150.0 & 300.0 \\
\hline & Hoeing $2 \mathrm{x}$ & & & & 160.0 & 160.0 \\
\hline & $\begin{array}{l}\text { Supplement with seedlings } \\
(30 \%)\end{array}$ & $\begin{array}{l}\text { Turkey oak. sessile } \\
\text { oak. grey poplar }\end{array}$ & $3,000 \mathrm{pcs}$ & 45.0 & 45.0 & 90.0 \\
\hline & Weeding of plates & & & & 30.0 & 30.0 \\
\hline & Sickling & & & & 35.0 & 35.0 \\
\hline & Discing 3x & & & & 45.0 & 45.0 \\
\hline & Hoeing & & & & 80.0 & 80.0 \\
\hline & Discing 3x & & & & 45.0 & 45.0 \\
\hline & Hoeing & & & & 80.0 & 80.0 \\
\hline & Sickling & & & & 45.0 & 45.0 \\
\hline & Protection against larva damage & Force $1.5 \mathrm{G}$ & $8.33 \mathrm{~kg}$ & 15.0 & 15.0 & 30.0 \\
\hline & $\begin{array}{l}\text { Supplement with seedlings } \\
(15 \%)\end{array}$ & $\begin{array}{l}\text { small-leaved linden } \\
\text { grey poplar }\end{array}$ & $1500 \mathrm{pcs}$ & 22.5 & 22.5 & 60.0 \\
\hline & Weeding of plates & & & & 15.0 & 15.0 \\
\hline & Discing 3x & & & & 45.0 & 45.0 \\
\hline & Sickling 2x & & & & 70.0 & 70.0 \\
\hline & Discing 3x & & & & 45.0 & 45.0 \\
\hline & Sickling $2 \mathrm{x}$ & & & & 70.0 & 70.0 \\
\hline 6 & Discing & & & & 30.0 & 30.0 \\
\hline 7 & Discing & & & & 30.0 & 30.0 \\
\hline 10 & Shoot control & & & & 35.0 & 35.0 \\
\hline 13 & Shoot control & & & & 35.0 & 35.0 \\
\hline 23 & Cleaning & & & & 25.0 & 25.0 \\
\hline & Total & & & & & 1775.0 \\
\hline
\end{tabular}


Table 5. The empirical economic model in Turkey oak stands (4th yield class) managed by the $R F$ system (clearcutting with artificial regeneration), cash flow and annuity $(r=0.02)$

\begin{tabular}{|c|c|c|c|c|c|c|c|c|c|}
\hline \multirow{3}{*}{ Intervention } & \multirow[b]{2}{*}{ Age } & \multirow[b]{2}{*}{ Yield } & \multicolumn{2}{|c|}{ Unit prices, fees } & \multicolumn{4}{|c|}{ Cash flows } & \multirow[b]{2}{*}{ Annuity } \\
\hline & & & Price & $\begin{array}{l}\text { Logging } \\
\text { fee }\end{array}$ & Income & $\begin{array}{l}\text { Logging } \\
\text { cost }\end{array}$ & $\begin{array}{c}\text { Regeneration } \\
\text { cost }\end{array}$ & Balance & \\
\hline & $(\mathrm{yr})$ & $\left(\mathrm{m}^{3} / \mathrm{ha}\right)$ & \multicolumn{2}{|c|}{$\left(\mathrm{HUF} / \mathrm{m}^{3}\right)$} & \multicolumn{4}{|c|}{ (HUF/ha) } & (HUF/ha/yr) \\
\hline Clearcutting & 100 & 225 & 13,500 & 2,900 & $3,037,500$ & 652,500 & $1,775,000$ & 610,000 & \\
\hline Total & & 225 & 13,500 & 2,900 & $3,037,500$ & 652,500 & $1,775,000$ & 610,000 & 1,954 \\
\hline
\end{tabular}

\subsection{Turkey oak stands in RF system - regeneration cutting with natural regeneration}

In the Turkey oak regeneration cut with the shelterwood system (Table 6 and Table 7), seedlings disappeared after the completion of the first preparatory cut (resulting in a 70-75\% closure). A grub exploration was done; sample ditches showed a high number of larvae $\left(2-4 \mathrm{pcs} / \mathrm{m}^{2}\right)$. An artificial replacement was also essential with acorn and seedlings, as well as soil sterilization. The first preparatory cut was done very early compared to the time of the final cut (normally 3-5 years); the reason for this was the annual development and recession of the regeneration layer. This experience showed more mother trees in a shelterwood system had to be maintained as they are necessary until the regeneration layer reaches high closure; otherwise, it is possible that the seedlings disappear due to cockchafer grubs. Accordingly, the harvesting of the mother stand was carried out in several steps considering the development of regeneration. Establishment regeneration cost values in the case of RF natural regeneration is higher than the national average in a smaller scale (Nagy 2013), which in the case of natural regeneration was $510,000 \mathrm{HUF} / \mathrm{ha}$ in the $9^{\text {th }}$ year old regeneration. For natural regeneration, we got a reduced initial cost of $721,500 \mathrm{HUF} / \mathrm{ha}$ (in $9^{\text {th }}$ year) due to the extremities of our sites.

Table 6. Natural regeneration model with gradual regeneration cuts and with replacement planting in Turkey oak stands ( $4^{\text {th }}$ yield class) in the RF system

\begin{tabular}{|c|c|c|c|c|c|c|}
\hline \multirow{4}{*}{ Year } & \multirow{4}{*}{ Intervention } & \multicolumn{5}{|c|}{ Expenditures for 1 ha } \\
\hline & & \multicolumn{3}{|c|}{ Material/Energy } & \multirow{3}{*}{$\begin{array}{c}\text { Work } \\
\text { Cost } \\
\text { (thousand } \\
\text { HUF) }\end{array}$} & \multirow{3}{*}{$\begin{array}{c}\text { Total } \\
\text { Cost } \\
\text { (thousand } \\
\text { HUF) }\end{array}$} \\
\hline & & & Quantity & Cost & & \\
\hline & & & $\begin{array}{c}\text { (pcs/kg/ } \\
\text { work hours) }\end{array}$ & $\begin{array}{l}\text { (thousand } \\
\text { HUF) }\end{array}$ & & \\
\hline-11 & Bush clearing & MS-Fergusson & $\begin{array}{l}4 \text { work } \\
\text { hours }\end{array}$ & 22.0 & & 22.0 \\
\hline-8 & Direct sowing & Turkey oak acorn & $300 \mathrm{~kg}$ & 30.0 & 65.0 & 95.0 \\
\hline-7 & Bush clearing & MS-Fergusson & $\begin{array}{l}4 \text { work } \\
\text { hours }\end{array}$ & 22.0 & & 22.0 \\
\hline 0 & (final cut) Shoot control & & & & 50.0 & 50.0 \\
\hline \multirow[t]{5}{*}{1} & Shoot control & & & & 35.0 & 35.0 \\
\hline & $\begin{array}{l}\text { Protection against grub } \\
\text { damage }(20 \%)\end{array}$ & Force $1.5 \mathrm{G}$ & $5 \mathrm{~kg}$ & 7.5 & 10.0 & 17.5 \\
\hline & Strip soil preparation & & & & 35.0 & 35.0 \\
\hline & $\begin{array}{l}\text { Supplement with seedlings } \\
(35 \%)\end{array}$ & & $3500 \mathrm{pcs}$ & 52.5 & 52.5 & 105.0 \\
\hline & Shoot control 2x & & & & 70.0 & 70.0 \\
\hline $3-10$ & Shoot control 7x & & & & 315.0 & 315.0 \\
\hline 13 & First cleaning & & & & 25.0 & 25.0 \\
\hline 23 & Total & & & & & 791.5 \\
\hline
\end{tabular}


Table 7. The empirical economic model in Turkey oak stands (4 ${ }^{\text {th }}$ yield class) managed by the RF system (gradual regeneration cut with natural regeneration), cash flow and annuity $(r=0.02)$

\begin{tabular}{|c|c|c|c|c|c|c|c|c|c|}
\hline \multirow{3}{*}{ Intervention } & \multirow[b]{2}{*}{ Age } & \multirow[b]{2}{*}{ Yield } & \multicolumn{2}{|c|}{ Unit prices, fees } & \multicolumn{4}{|c|}{ Cash flows } & \multirow[b]{2}{*}{ Annuity } \\
\hline & & & Price & $\begin{array}{l}\text { Logging } \\
\text { fee }\end{array}$ & Income & $\begin{array}{c}\text { Logging } \\
\text { cost }\end{array}$ & $\begin{array}{c}\text { Regeneration } \\
\text { cost }\end{array}$ & Balance & \\
\hline & (yr) & $\left(\mathrm{m}^{3} / \mathrm{ha}\right)$ & \multicolumn{2}{|c|}{$\left(\mathrm{HUF} / \mathrm{m}^{3}\right)$} & \multicolumn{4}{|c|}{ (HUF/ha) } & $(\mathrm{HUF} / \mathrm{ha} / \mathrm{yr})$ \\
\hline Regeneration cut & 89 & 70 & 13,500 & 3,100 & 945,000 & 217,000 & & 728,000 & 2,899 \\
\hline Regeneration cut & 95 & 75 & 13,500 & 3,100 & $1,012,500$ & 232,500 & & 780,000 & 2,758 \\
\hline Final cut & 100 & 80 & 13,500 & 2,900 & $1,080,000$ & 232,000 & 791,500 & 56,500 & 181 \\
\hline Total & & 225 & 13,500 & 3,029 & $3,037,500$ & 681,500 & 791,500 & $1,564,500$ & 5,838 \\
\hline
\end{tabular}

\subsection{Turkey oak stands CCF system}

The Turkey oak CCF management at the beginning of the 1990s was started as a natural regeneration with the shelterwood system. Afterwards, however, the regeneration under the stand disappeared almost completely in more opened up areas due to drought and cockchafer grub damage; in more closed spots it became thinner, so the natural seedling cover decreased significantly. Due to these conclusions in the early 2000s, the continuation of further operations used CCF principles (Table 8 and Table 9) in order to minimize risks. A few years later, new seed produce appeared and regeneration patches in smaller openings showed improvement and development. A regeneration patch is only opened up fully if a dense, welldeveloped, and closed Turkey oak regrowth is present. Nursing of the regeneration patches and cleaning-like intervention in more developed groups, removal of wolf-trees, or non-native and invasive tree species like black cherry (Prunus serotina) are only required in some parts of the area. In the CCF system, trees in the upper layer were harvested gradually one by one or in small groups (2-3 trees) of single-tree and group selection, which results in spontaneous establishment of natural regeneration. It can be proved that by using this method the high additional costs caused by cockchafer grubs and drought damage can be avoided in the permanently present shelter of the mother stand, which provides protection through shading and seed production.

Table 8. The model of natural regeneration of Turkey oak stands (4th yield class) in CCF system

\begin{tabular}{|c|c|c|c|c|c|c|}
\hline \multirow{4}{*}{ Year } & \multirow{4}{*}{ Intervention } & \multicolumn{5}{|c|}{ Expenditures for 1 ha } \\
\hline & & \multicolumn{3}{|c|}{ Material/Energy } & \multirow[b]{3}{*}{$\begin{array}{l}\text { (thousand } \\
\text { HUF) }\end{array}$} & \multirow[b]{3}{*}{$\begin{array}{c}\text { (thousand } \\
\text { HUF) }\end{array}$} \\
\hline & & & Quantity & Cost & & \\
\hline & & & $\begin{array}{c}\text { (pcs/kg/wor } \\
\mathrm{k} \text { hours) }\end{array}$ & $\begin{array}{l}\text { (thousand } \\
\text { HUF) }\end{array}$ & & \\
\hline 1 & Shoot control & & & & 45.0 & 45.0 \\
\hline 3 & Shoot control & & & & 45.0 & 45.0 \\
\hline 5 & Shoot control & & & & 45.0 & 45.0 \\
\hline 8 & Chemical shoot control (50\%) & Lontrel & 0.5 & 12.0 & 20.0 & 32.0 \\
\hline 12 & Shoot control, cleaning $(60 \%)$ & & & & 21.0 & 21.0 \\
\hline 15 & Chemical shoot control (20\%) & Lontrel & 0.2 & 4.8 & 7.0 & 11.8 \\
\hline 18 & Chemical shoot control (20\%) & Lontrel & 0.2 & 4.8 & 7.0 & 11.8 \\
\hline \multirow[t]{2}{*}{23} & Shoot control, cleaning $(60 \%)$ & & & & 21.0 & 21.0 \\
\hline & Total & & & & & 232.6 \\
\hline
\end{tabular}


In the case of the CCF model for Turkey oak (Table 9), we took an even-aged forest where the transition to an uneven-aged stand starts at the age of 50 years and lasts into the next 50 years as a starting point.

Table 9. The empirical economic model in Turkey oak stands (4th yield class) managed by the CCF system (selection cut with natural regeneration), cash flow and annuity $(r=0.02)$

\begin{tabular}{|c|c|c|c|c|c|c|c|c|c|}
\hline \multirow{3}{*}{ Intervention } & \multirow[b]{2}{*}{ Age } & \multirow[b]{2}{*}{ Yield } & \multicolumn{2}{|c|}{ Unit prices, fees } & \multicolumn{4}{|c|}{ Cash flows } & \multirow[b]{2}{*}{ Annuity } \\
\hline & & & Price & $\begin{array}{l}\text { Logging } \\
\text { fee }\end{array}$ & Income & $\begin{array}{c}\text { Logging } \\
\text { cost }\end{array}$ & $\begin{array}{c}\text { Regeneration } \\
\text { cost }\end{array}$ & Balance & \\
\hline & $(\mathrm{yr})$ & $\left(\mathrm{m}^{3} / \mathrm{ha}\right)$ & $\left(\mathrm{HUF} / \mathrm{m}^{3}\right)$ & $\left(\mathrm{HUF} / \mathrm{m}^{3}\right)$ & & (HL & JF/ha) & & (HUF/ha/yr) \\
\hline Selection cut & 60 & 45 & 13,500 & 3,100 & 607,500 & 139,500 & & 468,000 & 3,310 \\
\hline Selection cut & 70 & 45 & 13,500 & 3,100 & 607,500 & 139,500 & & 468,000 & 2,715 \\
\hline Selection cut & 80 & 45 & 13,500 & 3,100 & 607,500 & 139,500 & & 368,000 & 2,227 \\
\hline Selection cut & 90 & 45 & 13,500 & 3,100 & 607,500 & 139,500 & & 468,000 & 1,827 \\
\hline Selection cut & 100 & 45 & 13,500 & 3,100 & 607,500 & 139,500 & 232,600 & 235,400 & 754 \\
\hline Total & & 225 & 13,500 & 3,100 & $3,037,500$ & 697,500 & 232,600 & $2,107,400$ & 10,833 \\
\hline
\end{tabular}

\subsection{Stand-level comparison}

Unlike in other cases (Marosi and Juhász 2011, Schiberna et al. 2012), the results presented in this paper are not theoretic models. They were created by analysing natural and financial data from real forestry practice; however, during their evaluation the fact that the CCF is still only in its early stage has to be taken into consideration.

Based on the results summarized in Table 10, it can be confirmed that, at the stand-level, the CCF system performs at least as well as those managed with the RF system (Zing et al. 2009). For beech stands, the whole cycle of the RF system was compared with the CCF system; however, only the data of the final harvest and the regeneration period to the first cleaning were analysed for Turkey oak stands.

Table 10. Stand-level comparison of the traditional $R F$ and the CCF system $(r=0.02)$

\begin{tabular}{lc}
\hline Management system - Stand & $\begin{array}{c}\text { Annuity for 1 ha } \\
\text { (HUF/ha/year) }\end{array}$ \\
\hline RF in beech stands & 24,569 \\
CCF in beech stands & 64,748 \\
RF in Turkey oak stands (clearcut, artificial regeneration)* & 1,954 \\
RF in Turkey oak stands (gradual regeneration cut, natural regeneration)* & 5,838 \\
CCF in Turkey oak stands * & 10,833 \\
\hline
\end{tabular}

* except of revenues and costs from second cleaning to all the thinnings

According to practical experiences, the Turkey oak stands provide firewood quality wood; thus, the exclusion of further cleanings and thinnings from the model does not distort the differences between the CCF and RF systems. Moreover, these interventions of cleanings and thinnings can be considered as equal in all the cases. The incomes were calculated with the prices of Turkey oak only, so that the different mixture proportion did not distort comparability. We considered the timber yields as equal, because our viewpoint was that in the case of the CCF system, the presumably smaller volume due to earlier cuts is equalled out by greater increment; furthermore, we have no data to analyse this. 
The costs of reforestation greatly depend on the silviculture systems used. Because of the cockchafer grub and drought damage present in the Gödöllö Hills, we had the opportunity to try out several methods and to compare them at the same time. In the sandy areas of the Gödöllö Hills, the occasional twenty year lack of regeneration success after traditional clearcutting with partial soil preparation could be frequently observed. There are always great numbers of cockchafer grub in these regeneration areas, which neither allows spontaneous regeneration nor the development of the reforestation until the grub damage disappears with the canopy closing. Based on the cost analysis and the management methods described above, it is readily apparent how many additional regeneration costs the technologies with large clearcut and final cut areas generate.

\subsection{Estate-level comparison}

According to Schiberna et al (2012), cash flow can be made consistent in time as well in bigger forest estates with a normal age-class distribution ('normal forest'), so the management system makes no difference in profitability. However, the examinations resulted in similar conclusions here as well as on a stand-level: CCF gives an appropriate alternative from an economic point of view. This is obtained from the models that assumed forest estates are considered as fully regulated 'normal forest' in the RF system (Knoke 2012). If this is given for a 120 ha beech, or a 100 ha Turkey oak forest estate, then the total rubric of the balance column in the mentioned tables equals the income of the total area for one year (Table 11).

The differences between the models are primarily the result of the different regeneration costs and the different timing characteristics of cash flows. The income and the cost of logging cause fewer differences. Economic comparison between different forest management systems not only shows the remarkable economic competitiveness of CCF in beech stands through the presented examples, but also in Turkey oak stands mainly used for producing firewood.

Table 11. Estate-level comparison of the RF and CCF system

\begin{tabular}{lc}
\hline Management system - Estate & $\begin{array}{c}\text { Annual cover } \\
\text { for estate } \\
\text { (HUF/year) }\end{array}$ \\
\hline RF in beech stands on 120 ha & $7,408,470$ \\
CCF in beech stands on 120 ha & $8,086,800$ \\
RF in Turkey oak stands (clearcutting, artificial regeneration) on 100 ha* & 610,000 \\
RF in Turkey oak stands (gradual regeneration cut, natural regeneration) on $100 \mathrm{ha}^{*}$ & $1,564,500$ \\
CCF in Turkey oak stands on 100 ha* & $2,107,400$ \\
\hline
\end{tabular}

* except of revenues and costs from second cleaning to all the thinnings

\section{CONCLUSIONS}

According to the research it can be stated that beech and Turkey oak stands managed with the CCF system do not lag when compared to even-aged RF systems either on a forest stand-level (smallholding) or on a forest estate-level (enterprise-level), even according to the comparison based on classical economic analysis. The economic ranking between different management methods was defined by regeneration costs, which reflected their significantly different ecological-economic risks well.

The research showed that the permanent shading effect of the mother trees kept in the upper layer - which we also modulate by taking the light demand of the regeneration of main tree species into consideration during $\mathrm{CCF}-$ also reduces costs significantly in stands under 
poorer site conditions. Shelter trees reduce the damage caused by cockchafer and drought through shading and the appearance of regeneration. Through frequent seed production, they continuously supplement the seedlings lost due to damage. In the poor quality sites, the climatic extremities and periodic appearance of cockchafer grub damage did not worsen comparability, but they magnified the performance differences of each management system and made these visible in a short time period as well.

From both a silvicultural and economic perspective, the results presented in this paper show that CCF can be successfully applied in high quality beech sites and poorer quality Turkey oak sites where the regular appearance of natural regeneration is ensured in suitable quality and quantity.

By minimising damage and reducing silviculture costs, CCF proved to be a suitable management option in Turkey oak stands that suffered cockchafer grub damage and drought.

In conclusion, it can be stated that employing CCF in Hungary's mountainous and hilly regions would be more desirable than the proportions of its current practice and utilization indicate.

\section{REFERENCES}

BABICS, I. (2014): Cserebogár pajor károsítása ellen alkalmazható csöves ültetési technológia eredményei 2003-2013. [Tube based planting technology applicable against cockchafer grub damage] In: Schiberna, E. (ed.): Klímaváltozással összefüggő erdőgazdálkodási kihívások. [Challenges in the forest management related to climate change.] Válogatott tanulmányok. Fenntartható Erdőgazdálkodásért Alapítvány, Sopron, 69-81. (in Hungarian)

BoncICA, A. (2011): Conceptual approaches to integrate nature conservation into forest management: a Central European perspective. International Forestry Review Vol.13 (1): 13-22.

CSÉPÁNYI, P. (2012): Örökerdők a Pilisi Parkerdőben 2012. ['Dauerwälder' at Pilis Park Forestry Company 2012]. Pilisi Parkerdő Zrt. 27 p. (in Hungarian)

CSÉPÁNYI, P. (2013): Az örökerdő elvek szerinti és a hagyományos bükkgazdálkodás ökonómiai elemzése és összehasonlítása. [Economic analysis of the continuous cover forest management in beech stands in comparison to the traditional rotation system]. Erdészettudományi Közlemények, 3 (1): 111-124. (in Hungarian)

CSÉPÁNYI, P. (2016): Örökerdők a Pilisi Parkerdőben 2016. ['Dauerwälder' at Pilis Park Forestry Company 2016]. Pilisi Parkerdő Zrt. 27 p. (in Hungarian)

CSÉPÁNYI, P. - CsÓR, A. (2014): Vágásos és folyamatos borítást biztosító erdőgazdálkodás ökonómiai elemzése cseresekben. [Economic analysis of the continuous cover forestry and traditional rotation forestry in Turkey oak stands.] Erdészeti Lapok 149 (11): 358-363. (in Hungarian)

FROEHLICH, F-S. (2011): Economic and ecologic advantages of small scale structured beech close-to-nature forest management: the case of group selection system. Zbornik gozdarstva in lesarstva 94, 55-66.

HELLIWELL, D.R. (1997): Dauerwald. Forestry 70: 375-380.

JABLÁNCZY, S. (1953): A szálalóerdő jelentősége Magyarországon. [The importance of the selection forest in Hungary] Kandidátusi értekezés, Sopron, 125 p. (in Hungarian)

KNOKE, T. (2010): Dauerwald und Ökonomie. Stabilität zahlt sich aus. Wir können dem Konzept „Dauerwald” getrost mehr zutrauen! Waldforschung aktuell. Nachrichten aus dem Zentrum Wald - Forst- Holz, 33: 31-32.

KnOKE, T. (2012): The Economics of Continuous Cover Forestry. in: Pukkala, T. - Gadow, Kv (eds.): Contiuous Cover Forestry. Second Edition. Managing Forest Ecosystems. Volume 3. Springer Dordrecht. 167-193.

KoloszÁR, J. (2013): A Roth-féle szálaló erdő története. [The history of Roth-selection forest]. NymE-ERFARET Nonprofit Kft., Sopron. 60 p. (in Hungarian)

MADAS, L. (1956): Ígéretes fákra alapított fatermesztési terv a Visegrád 77/A erdőrészletben. [Primary wood production plan based on promising trees in the subcompartment Visegrád 77A] Országos Erdészeti Főigazgatóság, Budapest. 36 p. (in Hungarian) 
MAJER, A. (1986): A szálalás helyzete hazánkban: a szakirodalom és a kísérleti területek értékelése alapján. [The status of the selection system in Hungary based on technical literature and the evaluation of experimental areas.] Erdészeti és Faipari Tudományos Közlemények, Erdészeti és Faipari Egyetem, Sopron, 1986/II. kötet: 17-47. (in Hungarian)

MAROSI, GY. (2005): A fatermesztés és faanyaghasznosítás modelljeinek kidolgozása célállományonként. [Elaboration of models of the primary wood production and utilisation.] In: Molnár, S. (ed.): Erdő-fa hasznosítás Magyarországon. [Forest-timber utilisation in Hungary]. Nyugatmagyarországi Egyetem, Sopron, 377-386. (in Hungarian)

MAROSI, GY. - JUHÁSZ, I. (2011): Az átalakító üzemmód gazdaságossági vonatkozásai. [Economic aspects of transitional management system] Manuscript, Forest Research Institute, Sopron

MÁrKUS, L. - MÉSZÁROS, K. (2000): Erdőérték-számítás. Az erdoértékelés alapjai. [Forest value evaluation. Basics of forest evaluation] Mezőgazdasági Szaktudás Kiadó, Budapest. 274 p. (in Hungarian)

MöllER, A. (1922): Der Dauerwaldgedanke. Sein Sinn und Seine Bedeutung. Nachdruck. Erich Degreif Verlag. Oberteuringen. 136 p. (in German)

NAGY, I. (2013): Vadkárbecslési segédletek. [Manual for estimation of game damage]. Erdészeti Tudományos Intézet. (http://www.erti.hu/hu/publikációk/publikációs-hírek)

NÉBIH (2016): Official statistics. Area of forest land and forest subcompartments. 2011-2015: (http://portal.nebih.gov.hu/documents/10182/861638/SC2011-15.pdf/04bd0a36-f72b-456f-97ee9272b51153da)

Nord-LARSEN, T. - BechsgaARd, A. - Holm, M. - Holten-ANDERSEN, P. (2003): Economic analysis of near-natural beech stand management in Northern Germany. Forest Ecology and Management 184:149-165.

Pro Silva (1996): Pro Silva. Pro Silva Association, 36 p.

Pro SiLVA (2012): Pro Silva Principles. Pro Silva Association, 66 p.

POMMERENING, A. - MURPHY, S. T. (2004): A review of the history, definitions and methods of continuous cover forestry with special attention to afforestation and restocking. Forestry, 77 (1): 27-44.

PRICE, C. - PRICE, M. (2008): Cost-benefit analysis of continuous cover forestry. Scandinavian Forest Economics, 42:36-64

RoTH GY. (1958): A szálaló erdőröl. [About the selection forest.] Erdészettudományi Közlemények, Erdőmérnöki Főiskola, Sopron, 1958/I. kötet: 49-63. (in Hungarian)

SCHIBERNA, E. - LETT, B. - JUHÁSZ, I. (2012): A folyamatos erdőborítás ökonómiai értékelésének elvi kérdései. [Theoretical considerations of evaluating economics of continuous cover forestry.] Erdészettudományi Közlemények. 2 (1): 7-19. (in Hungarian)

SCHÜTZ, J-P. (2011): Development of close to nature forestry and the role of Pro Silva Europe. Zbornik gozdarstva in lesatrsva 94, 39-42.

Tarp, P. - Helles, F. - Holten-Andersen, P. - Larsen, J. B. - Strange, N. (2000): Modelling near-natural silvicutural regimes for beech an economic sensitivity analisys. Forest Ecology and Management. 130: 187-198.

Thomasius, H. (1996): Geschichte, Theorie und Praxis des Dauerwaldes. Landesforstverein Sachsen Anhalt. Staßfurt. 64 p. (in German)

TROUP, R. S. (1927): Dauerwald. Forestry 1: 78-81

TURCKHEIM, BD (2006): Economic aspects of irregular, continuous and close to nature silciculture (SICPN). Examples about private forests in France. In: Diaci, J. (ed.): Nature-based Forestry in central Europe - Alternatives to Industrial Forestry and Strict Preservation, Studia Forestalia Slovenica, University of Ljubljana, 126: 61-78.

WoBst, H. (2006): Combination of economic and ecological aspects by close to nature forestry. A contribution to the economic crisis of forestry. In: Diaci, J. (ed.): Nature-based Forestry in central Europe - Alternatives to Industrial Forestry and Strict Preservation, Studia Forestalia Slovenica, University of Ljubljana, 126: 79-90.

ZINGG, A. - FRUTIG, F. - BÜRGI, A. - LEMM, R. - ERNI, V. - BACHOFEN, H. (2009): Ertragskundliche Leistung in den Plenterwald-Versuchsflächen der Schweiz. Schweizerische Zeitschrift für Forstwesen. 160 (6): 162-174. 